Баришевська I. В., кандидат економічних наук, доцент кафедри фінансів, банківської справи та страхування, Миколаївський національний аграрний університет, м. Миколаїв, Україна

ORCID: 0000-0003-3851-160X

e-mail: baryshevskaIV@mnau.edu.ua

Малишенко Ю. Г., здобувач вищої освіти обліково-фінансового факультету, Миколаївський національний аграрний університет, м. Миколаїв, Україна

e-mail: ymal13497@gmail.com

Склева К. В., здобувач вищої освіти обліково-фінансового факультету, Миколаївський національний аграрний університет, м. Миколаїв, Україна

e-mail: skleva1996@gmail.com

\title{
Інноваційна стратегія підприємства як джерело його конкурентних переваг
}

Анотація. У статті розкрито поняття «інноваційна стратегія» та «інноваційна стратегія розвитку підприємства». Визначено, що стратегічний план підприємства визначає цілі та напрями розвитку у всіх сферах господарської діяльності, в тому числі щодо інновацій. Наведені основні вісім етапів стратегії інноваційного розвитку, які виділяє О. І. Дідченко. Розглянуто типи інноваційної стратегії підприємства за К. Фріменом. Висвітлено основні елементи, які охоплює наступальна стратегія. Наведено приклад наступальної інноваційної стратегії. Визначено найважливіший фактор для здійснення захисної стратегії. Розглянуто шляхи втілення у життя імітаційної інноваційної стратегії. Досліджено основні переваги підприємства, що застосовує імітаційну стратегію. Розкрито сутність поняття «залежна інноваційна стратегія». Наведені основні аспекти традиційної стратегії підприємства. Проаналізовані приклади традиційної стратегії. Висвітлено основні особливості інноваційної стратегії «за нагодою».

Ключові слова: інновація; стратегія; розвиток; інвестиції; ресурс.

Baryshevskaya Inna, PhD (Economics), Associate Professor of the Department of Finance, Banking and Insurance, Mykolayiv National Agrarian University, Mykolayiv, Ukraine

Malyshenko Yurii, applicant for higher education of Accounting and Finance faculty, Mykolayiv National Agrarian University, Mykolayiv, Ukraine

Skleva Konstiantyn, applicant for higher education of Accounting and Finance faculty, Mykolayiv National Agrarian University, Mykolayiv, Ukraine

\section{Innovation strategy of the company as a source of its competitive advantages}

Abstract. Introduction. Innovative development is an integral and active part of all spheres of life of a society and, in particular, the enterprise as its primary link. The importance of innovation development for enterprises can not be overemphasized: only through innovation can the competitiveness of products be ensured both on the domestic and on the world market.

Innovation activity is one of the main components of the process of ensuring the successful operation of enterprises. Therefore, modern economic conditions require intensive innovation activity, effective organization of research and development, innovations, reduction of innovation risks, strategic management in the innovation activity of each enterprise.

Purpose. The purpose of the article is to reveal theoretical aspects of development of the strategy of innovative development of enterprises in modern economic conditions.

Results. Innovative development strategy of an enterprise is a set of goals and installations, rules of decisionmaking and methods of transferring an enterprise from the old (present) state to a new (target) state on the basis of the introduction of innovations - technological, product, organizational, managerial, economic, social and positioning of the enterprise on competitive markets for goods and services. That is why, the innovation strategy is always expressed in determining the type of target behavior of the enterprise in the competitive markets.

Innovation strategy refers to the level of functional strategies. The strategic plan of an enterprise defines goals and directions of development in all spheres of economic activity, including innovations. 
K.Freeman gives the most perfect classification of the types of innovative strategy of the enterprise. It distinguishes six types of innovation strategy of the enterprise: offensive, protective, simulation, dependent, traditional and strategy "by chance".

Conclusions. Innovations in the enterprise are conditioned by economic necessity, since maintaining an adequate level of competitiveness in modern conditions is impossible without investing in research and development, developing or acquiring new technologies, developing new product launches, developing sales channels, maintaining a positive brand image, etc.

Innovations are the most effective way to find the various ways and means to increase sales and increase profits for an enterprise.

Keywords: innovation; strategy; development; investment; resource.

JEL Classification: 030, 031, Q10.

Постановка проблеми. Одним із перспективних шляхів економічного зростання підприємств $€$ їх інноваційний розвиток. Практика господарювання свідчить, що інноваційні перебудови на сучасному етапі розвитку підприємств можуть не лише забезпечити високі показники економічного розвитку, але й підвищити їх конкурентоспроможність та експортний потенціал, а також допоможуть вирішити економічні, екологічні, соціальні проблеми. Інноваційний розвиток $є$ невід'ємною та активною частиною всіх сфер життєдіяльності суспільства і, зокрема, підприємства як його первинної ланки. Значення інноваційного розвитку для підприємств важко переоцінити: тільки через інновації можна забезпечити конкурентоспроможність продукції як на вітчизняному, так і на світових ринках.

Інноваційна діяльність $€$ однією 3 основних складових процесу забезпечення успішного функціонування підприємств. Тому сучасні економічні умови вимагають інтенсивної інноваційної діяльності, ефективної організації досліджень та розробок, нововведень, зниження інноваційних ризиків, стратегічного управління в інноваційній діяльності кожного підприємства.

Послідовна активізація інноваційної діяльності підприємства за всіма напрямами функціонування дозволяє одержувати нові технологічні процеси, продукцію або форми організації та управління виробництвом, що забезпечує досягнення і зміцнення конкурентних позицій на ринку та вплив на ринкову ситуацію завдяки реалізації інновацій. При цьому функціонування підприємств у довгостроковій перспективі пов'язано 3 формуванням стратегії розвитку, орієнтованої на посилення інноваційної активності.

Формування означеної стратегії являє собою процес прийняття управлінського рішення щодо змісту функціональних стратегій такого роду та пріоритетності їх фінансування з метою забезпечення конкурентних переваг на ринку.

Аналіз останніх досліджень і публікацій. Проблемам інноваційної стратегії підприємств приділяється багато уваги вітчизняних та зарубіжних науковців. Цим питанням присвячені роботи Б. Буркинського, А. Гальчинського, В. Гейця, О. Дідчен- ко [6], О. Ковтун [7], К. Орєхової [9], В. Орлової [10] та інших.

Формулювання цілей дослідження. Метою статті $\epsilon$ розкриття теоретичних аспектів розробки стратегії інноваційного розвитку підприємств в сучасних умовах господарювання.

Виклад основного матеріалу дослідження. У науковій літературі $з$ управління інноваціями не сформувалося єдиного підходу до визначення змісту поняття «інноваційна стратегія». Можливо, це визначається складністю і неоднозначністю розуміння сутності самої інновації як економічної категорії. Огляд визначень різних дослідників свідчить, що даний термін може мати різні значення залежно від контексту, а вибір підходу до визначення поняття залежить від конкретних цілей вимірювання або аналізу.

Інновації - це кінцевий результат інноваційної діяльності, у вигляді нового чи удосконаленого продукту або технологічного процесу, який наділено якісними перевагами при використанні та проектуванні, виробництві, збуті, використовується у практичній діяльності та має суспільну перевагу.

Інноваційна стратегія - це узгоджена сукупність управлінських рішень, що впливають на інноваційну діяльність підприємства і мають довгострокові наслідки [6].

Інноваційна стратегія розвитку підприємства - це комплекс цілей і установок, правил прийняття рішень і способів переходу підприємства зі старого (наявного) стану в новий (цільовий) стан на основі впровадження інновацій - технологічних, продуктових, організаційних, управлінських, економічних, соціальних і позиціювання підприємства на конкурентних ринках товарів і послуг. Тобто інноваційна стратегія завжди виражається у визначенні типу цільової поведінки підприємства на конкурентних ринках.

Інноваційна стратегія відноситься до рівня функціональних стратегій. Стратегічний план підприємства визначає цілі та напрями розвитку у всіх сферах господарської діяльності, в тому числі щодо інновацій. При цьому для деяких агресивних інноваційних підприємств стратегія у сфері інновацій $є$ найбільш значущим елементом корпоративної стратегії. У будь-якому випадку інноваційна стратегія підприємства повинна бути органічно пов'язана зі 
стратегією бізнесу й орієнтована на реалізацію спільних стратегічних цілей та принципів в інноваційній сфері [7].

Стратегія інноваційного розвитку підприємства має такі притаманні їй риси:

1. Процес розробки закінчується формуванням загальних напрямів, які спроможні забезпечити економічне зростання.
2. Істотним $€$ посилення зворотного зв'язку, що дозволяє здійснювати пошук найбільш обґрунтованих рішень з безлічі нових альтернативних варіантів та коригувати раніше сформульовані стратегічні цілі інноваційного розвитку.

3. Притаманна невизначеність, що пов'язано 3 неможливістю передбачення шляхів розвитку [6].

Дідченко О.І. виділяє вісім етапів стратегії інноваційного розвитку (рис. 1).

\begin{tabular}{|c|}
\hline Етапи стратегії інноваційного розвитку \\
\hline визначення загального періоду формування стратегії інноваційного розвитку \\
\hline дослідження факторів середовища \\
\hline оцінка сильних і слабких сторін інноваційної діяльності підприємства \\
\hline комплексна оцінка стратегічної позиції підприємства \\
\hline формування стратегічних цілей інноваційної діяльності \\
\hline розроблення цільових стратегічних нормативів інноваційної діяльності \\
\hline прийняття основних стратегічних інноваційних рішень \\
\hline $\begin{array}{l}\text { оцінка розробленої стратегії інноваційного розвитку, а також два етапи } \\
\text { реалізації стратегії: забезпечення реалізації стратегії і організація контролю за її } \\
\text { реалізацією }\end{array}$ \\
\hline
\end{tabular}

Рисунок 1 - Етапи стратегії інноваційного розвитку

Джерело: побудована авторами на основі даних [6]

Коли ми розглядаємо інноваційну стратегію підприємства, технологічні зміни $€$ складовою навколишнього середовища, а ресурси технологічних змін розуміють як вхідні параметри. Це може бути куплена ліцензія, запозичена технологія чи продукт, копіювання організаційних чи збутових нововведень. Найбільш досконалу класифікацію видів інноваційної стратегії підприємства дає К. Фрімен. Він розрізняє шість типів інноваційної стратегії підприємства (рис 2).

Наступальна інноваційна стратегія охоплює:

- активні науково-дослідні та дослідноконструкторські роботи (НДДКР), орієнтовані на маркетинг;

- стратегію злиття;

- стратегію придбання.

Наступальні стратегії звичайно потребують кредитних інвестицій, отже, більше використовуються на підприємствах, що мають достатньо високий фінансовий потенціал, кваліфікований склад менеджерів і творчого науково-технічного потенціалу [5].
Наступальна чи агресивна інноваційна стратегія пов'язана 3 прагненням підприємства досягти технічного та ринкового лідерства шляхом створення та впровадження нових продуктів. Така стратегія передбачає:

1) щільний зв'язок фірми зі світовими досягненнями науки й технології;

2) пряму залежність від наукових розробок, що фінансуються та здійснюються самою фірмою;

3) можливість фірми швидко реагувати та пристосовуватися до нових технологічних можливостей.

При реалізації наступальної стратегії головну роль відіграє спеціальний підрозділ підприємства, що займається дослідженнями та розробками. Така стратегія дає можливість фірмі користуватись новою технологією набагато раніше, ніж це зроблять ії конкуренти. А при патентному захисті нової технології утворюється тимчасова монополія на прибуток інноватора [9]. 


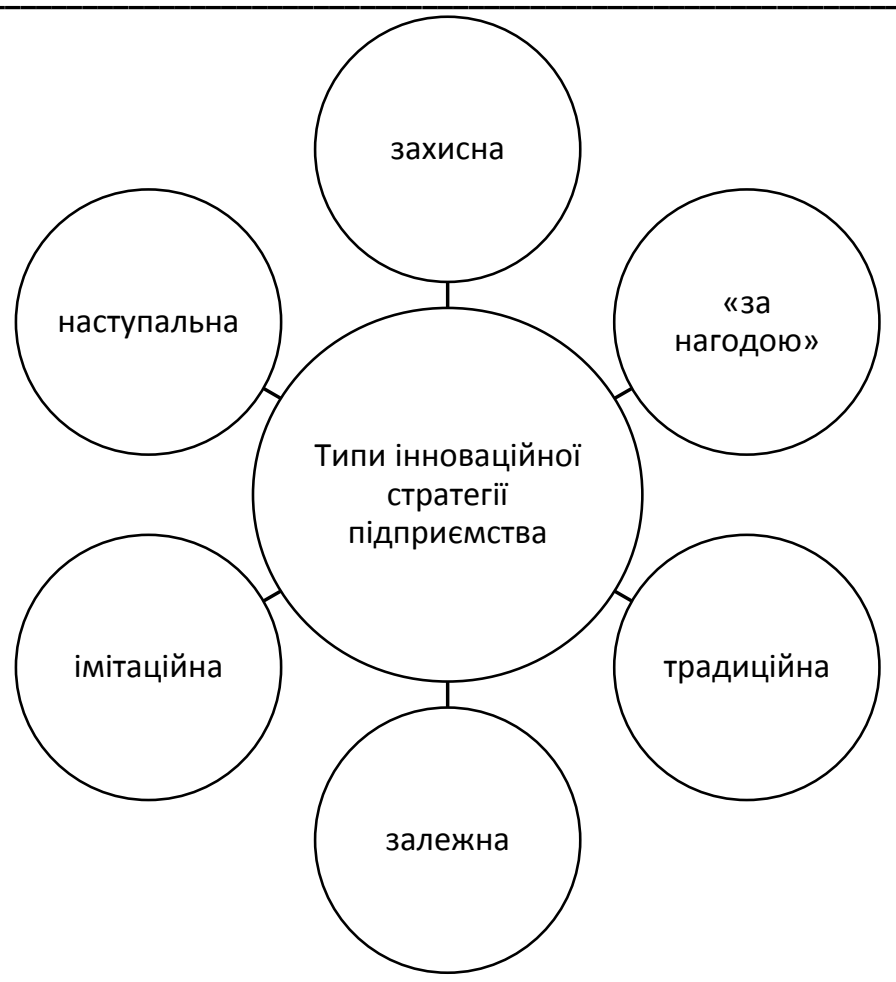

Рисунок 2 - Типи інноваційної стратегії підприємства

Джерело: побудована авторами на основі даних [5]

Прикладами наступальної інноваційної стратегії були виробництво телевізорів, нейлону, напівпровідників. Але наступальна інноваційна стратегія $\epsilon$ досить ризиковою, тому більшість фірм, що можна віднести до високоінноваційних дотримуються захисної стратегії.

Захисна інноваційна стратегія відбиває реакцію підприємства на дії конкурентів і пов'язана 3 опануванням нової технології й завдяки їй виходом на нові ринки. Захисна стратегія вимагає від підприємства:

1) високої мобільності;

2) уваги навчанню свого персоналу та рекламі;

3) високої наукомісткості та значних зусиль дослідників;

4) уваги аналізу досягнень й помилок фірм партнерів;

5) технічного обслуговування та сервісу [5].

Найважливішим фактором для здійснення захисної стратегії $€$ придбання патентів. Підприємствазахисники є споживачами патентів і постачальниками прибутків для фірм-«форвардів».

Імітаційна інноваційна стратегія пов'язана 3 копіюванням технології виробництва продукції фірмпіонерів. Використання цієї стратегії не дуже віддалене в часі від першого використання базової інновації, і як правило, пов'язане 3 придбанням ліцензії на виробництво такого продукту [5].

Імітаційна інноваційна стратегія пов'язана 3 копіюванням технології виробництва продукції фірм- піонерів. Вона може бути втілена у життя двома шляхами:

- купівля ліцензії на виробництво продукції;

- фірма має досить технологічних знань, щоб зімітувати інноваційний продукт.

В будь-якому випадку підприємство, що застосовує імітаційну стратегію, повинно мати певні переваги у виробництві аналогічної продукції у порівнянні 3 фірмами-піонерами.

Такими перевагами можуть бути:

- зниження вартості продукції завдяки залученню дешевої робочої сили чи місцевих природних ресурсів;

- використання вже наявних потужностей у новому призначенні.

Таким чином, імітаційна стратегія $є$ вдалою тільки за умови додавання технічних, економічних та споживчих якостей до оригіналу.

Для того, щоб проводити цю стратегію, фірмі потрібно мати кваліфікований науково-технічний персонал, який зможе опанувати та удосконалити інновацію, знає кон'юнктуру відповідних ринків, має вихід у світовий інформаційний простір, виявляє успіхи та невдачі фірм-піонерів [5].

Залежна інноваційна стратегія - це тип стратегічної поведінки, за якої характер технологічних змін залежить від політики інших фірм, які виступають як «батьківські» фірми в коопераційних технологічних зв'язках. Найчастіше «залежні» фірми виконують субпідрядні роботи та не змінюють самостійно свою продукцію, тому що вимоги до якості продукції 
встановлює головна фірма. Вимоги щодо розвитку науково-технічних рис у таких фірмах мінімальні.

Традиційна інноваційна стратегія означає відсутність технологічних змін на підприємстві. На традиційних виробництвах закріплюються певні інноваційні форми на тривалий період їх «життєвого циклу». Дана стратегія передбачає осмислену відмову від оновлення продукції внаслідок ретельного аналізу ринкової ситуації й стану конкурентів, але не уникає власне інноваційної поведінки, оскільки пов'язана 3 удосконаленням форми й сервісу традиційної продукції [7].

Прикладом традиційної стратегії може бути ресторанний або готельний бізнес. При всій традиційності задоволення попиту форма і якість такої продукції постійно удосконалюються.

Інноваційна стратегія «за нагодою» у довгостроковий період часу пов'язана зі швидким опануванням інформації й можливостей, які виникають у зовнішньому середовищі підприємства. Характерною рисою цієї стратегії є відсутність власної науково-технічної діяльності. Такий тип поведінки ще називають «стратегією ніші», оскільки перевага полягає у знаходженні особливої ніші на наявних ринках товарів і послуг, яка має споживача 3 нетиповими, але різноманітними потребами [5].

Ця стратегія має сенс тільки тоді, коли є першим кроком до інших стратегій. Без цього такий тип стратегічної поведінки є безперспективним.

Висновки. Отже, інновації на підприємстві зумовлюються економічною необхідністю, оскільки підтримка належного рівня конкурентоспроможності в сучасних умовах неможлива без інвестицій у науководослідні та дослідно-конструкторські роботи, розробку або придбання нових технологій, освоєння випуску нових продуктів, розвиток каналів збуту, підтримку позитивного іміджу торгової марки тощо. Крім того, в умовах обмеження ресурсів для відшкодування витрат, які постійно зростають, підприємства постають перед проблемою пошуку різних шляхів і можливостей збільшення обсягів продажу та зростання прибутку. Найефективнішим способом $є$ інновації. Відповідно, конкуренція на їх основі викликає потребу розробки стратегії інновацій, яка стосується всіх підсистем підприємства і зводиться до певного стратегічного набору (портфеля) інноваційного змісту.

\section{Література:}

1. Daniel, I. (2016). "Prajogo The strategic fit between innovation strategies and business environment in delivering business performance", International Journal of Production Economics. https://doi.org/10.1016/j.ijpe.2015.07.037 (Accessed 02 September 2018).

2. Zarrabi, F. Poursadegh, N. and Jafarvand, S. (2013). "Alignment between Innovation Strategy and Out Comes". Procedia Social and Behavioral Sciences, vol. 75, pp. 18-24. https://doi.org/10.1016/j.sbspro.2013.04.003 (Accessed 02 September 2018).

3. Freeman, C. (1982). "The Economics of industrial innovation", The MIT Press.

4. Hittmar, S. Varmus, M. and Lendel, V. (2014). "Proposal of Model for Effective Implementation of Innovation Strategy to Business", Procedia - Social and Behavioral Sciences, vol. 109, pp. 1194-1198. https://doi.org/10.1016/j.sbspro.2013.12.611 (Accessed 02 September 2018).

5. Види інноваційних стратегій та їх співвідношення [Електронний ресурс]. - Режим доступу: https://subject.com.ua/economic/innovative/12.html.

6. Дідченко О. І. Сутність поняття «інноваційний розвиток» підприємства / О. І. Дідченко, А. В. Ткачук // Економічний вісник ДВН3 «Український державний хіміко-технологічний університет». - 2015. - № 2. - С. 36-41.

7. Ковтун О. І. Інноваційні стратегії підприємств: теоретико-методологічні засади [Електронний ресурс]. - Режим доступу: www.irbis-nbuv.gov.ua

8. Баришевська І. В. Організаційно-економічний механізм розвитку інноваційного підприємництва в аграрному секторі економіки / І. В. Баришевська, О. І. Мельник // Australian Journal of Scientific Research. - 2014. - № 1 (5) (January-June). - C. 482488.

9. Орєхова К. В. Формування інвестиційної стратегії підприємства / К.В. Орєхова // Інвестиції: практика та досвід. - 2014. - № 21. - С. 14-17.

10. Орлова В. М. Стратегія інноваційного розвитку підприємства [Електронний ресурс] // Економічний нобелівський вісник. - Режим доступу: http://econforum.duan.edu.ua/images/stories/Files/2015/12.pdf

\section{References:}

1. Daniel, I. (2016). "Prajogo The strategic fit between innovation strategies and business environment in delivering business performance". International Journal of Production Economics. https://doi.org/10.1016/j.ijpe.2015.07.037 (Accessed 02 September 2018).

2. Zarrabi, F. Poursadegh, N. and Jafarvand, S. (2013). "Alignment between Innovation Strategy and Out Comes". Procedia Social and Behavioral Sciences, vol. 75, pp. 18-24. https://doi.org/10.1016/j.sbspro.2013.04.003 (Accessed 02 September 2018).

3. Freeman, C. (1982). "The Economics of industrial innovation", The MIT Press.

4. Hittmar, S. Varmus, M. and Lendel, V. (2014). "Proposal of Model for Effective Implementation of Innovation Strategy to Business", Procedia - Social and Behavioral Sciences, vol. 109, pp. 1194-1198. https://doi.org/10.1016/j.sbspro.2013.12.611 (Accessed 02 September 2018).

5. Types of innovation strategies and their relationships, available at: https://subject.com.ua/economic/innovative/12.html (Accessed 02 September 2018). 
Електронне наукове фахове видання з економічних наук "Modern Economics», №11 (2018), 13-18 https://modecon.mnau.edu.ua | ISSN 2521-6392

6. Didchenko, O. I. and Tkachuk, A. V. (2015). "The essence of the concept of "innovative development" of the enterprise", Economic Newswire of the Ukrainian State Chemical Technology University, availabe at: http://nbuv.gov.ua/UJRN/evdvnz_2015_2_9 (Accessed 02 September 2018)

7. Kovtun, O. I., "Innovative strategies of enterprises: theoretical and methodological principles", availabe at: www.irbisnbuv.gov.ua (Accessed 02 September 2018).

8. Baryshevskaya, I. V. and Melnyk, O. I. (2014). “Organizational and Economic Mechanism for the Development of Innovative Entrepreneurship in the Agrarian Sector of the Economy", Australian Journal of Scientific Research, no. 1 (5), pp. $482-488$.

9. Orekhova, K. V. (2014). "Formation of enterprise investment strategy". Investments: practice and experience, available at: http://www.investplan.com. ua/?op=1\&z=4026\&i=2 (Accessed 02 September 2018).

10. Orlova, V. M. "Strategy of innovative development of the enterprise", [Online], available at: http://econforum.duan.edu.ua/images/stories/Files/2015/12.pdf (Accessed 02 September 2018).

Ця робота ліцензована Creative Commons Attribution 4.0 International License 